\title{
"Trening orientacji i zarządzania czasem" w toku czynności dnia codziennego z osobami z niepełnosprawnością intelektualną w stopniu umiarkowanym
}

\begin{abstract}
Magdalena Hinc-Wirkus, "Trening orientacji i zarządzania czasem" $w$ toku czynności dnia codziennego z osobami z niepetnosprawnościa intelektualna w stopniu umiarkowanym ["The time workshop" with persons with the moderate intellectual disability]. Interdyscyplinarne Konteksty Pedagogiki Specjalnej, nr 17, Poznań 2017. Pp. 197-31. Adam Mickiewicz University Press. ISSN 2300-391X

The man is a social being - instinctively is aspiring to the full involvement in the society. However is showing the statistician - tenth polish people must overcome problems in order can act actively. What problems must stand up persons with intellectual disability and their carers? One of the main barier of persons with intellectual disability are problems with perception of the time:using notions of the time, learning use the watch, comprehending the calendar. A simple and cheap way to this skills is the the training of the time ("the time workshop"). I will describe it in this article
\end{abstract}

KEY WORDS: moderate intellectual disability, the time workshop, comprehending of the time 


\section{Wprowadzenie}

Niepełnosprawność intelektualna w stopniu przynajmniej umiarkowanym ${ }^{1}$ stanowi minimum $1 \%$ społeczeństwa. Jedną z większych, bo codziennych trudności $\mathrm{w}$ funkcjonowaniu osób $\mathrm{z}$ taką niepełnosprawnością wydaje się percepcja czasu, wyrażająca się z jednej strony w psychicznym aspekcie percepcji rzeczywistości ( $w$ orientacji w niej), z drugiej - pragmatyczniej - w korzystaniu z pojęć temporalnych, pojmowaniu kalendarza, $\mathrm{w}$ obsłudze i sensie istnienia zegarka itp. Istnieją jednak proste i tanie sposoby, by przeprowadzić "trening orientacji i zarządzania czasem" (w skrócie "trening czasu") z takimi osobami.

Należy na wstępie wyjaśnić, że treningi dotyczące codziennych aktywności osoby z niepełnosprawnością są pewną wyodrębnioną formą oddziaływań stosowanych w pracy socjalnej (np. jako usługi społeczne realizowane przez pracownika socjalnego lub asystenta osoby niepełnosprawnej), ale także stosowane są $\mathrm{w}$ pedagogice specjalnej. Dorota Podgórska-Jachnik zwraca uwagę, że coraz częściej używa się określenia treningu tam, gdzie dotąd chętnie posługiwano się pojęciem terapii (np. ergoterapii)2. Pojęcie treningu wydaje się określeniem precyzyjniejszym, bardziej konkretnym z punktu widzenia wyodrębnienia strukturalnego podejmowanych zadań i bardziej adekwatnym do faktycznych działań opiekunów. Nie kwestionuje się jego efektu terapeutycznego, ale nazewnictwo odzwierciedla aktualne tendencje w pedagogice specjalnej - potrzeby bardzo ostrożnego używania określenia „terapia”, ograniczone-

${ }^{1}$ Zgodnie z polskim orzecznictwem lekka niepełnosprawność intelektualna nie jest traktowana jeszcze jako niepełnosprawność (orzecznictwo MPiPS), choć uczniowie $\mathrm{z}$ takim stopniem mogą uzyskać orzeczenie o potrzebie kształcenia specjalnego (orzecznictwo MEN). Realizują jednak tę samą podstawę programową, choć $\mathrm{z}$ dostosowaniami dydaktycznymi. Niepełnosprawność intelektualna w stopniu umiarkowanym i znacznym to już odrębne programy nauczania, i orzeczenie o (stopniu) niepełnosprawności. Oznacza zatem już poważne ograniczenia, tak w uczeniu się, jak i w funkcjonowaniu społecznym.

${ }^{2}$ D. Podgórska-Jachnik, Praca socjalna $z$ osobami z niepetnosprawnością $i$ ich rodzinami, Centrum Rozwoju Zasobów Ludzkich, Warszawa 2014, s. 140. 
go dla pewnych bardziej zaawansowanych działań interwencyjnych ${ }^{3}$. Treningi mają konkretnie określony, wąski zakres umiejętności, ściśle zaplanowaną strukturę, metodykę nabywania kompetencji, ograniczony czas działania, a także wyraźnie zoperacjonalizowane i proste do zweryfikowania oczekiwane efekty4. Wszystko to wydaje się sprzyjać metodyce pracy $\mathrm{z}$ osobami $\mathrm{z}$ niepełnosprawnością intelektualną.

\section{Ograniczenia funkcjonalne wynikające z niepełnosprawności intelektualnej w stopniu umiarkowanym}

Niepełnosprawność intelektualna według definicji Światowej Organizacji Zdrowia to: „istotne obniżenie ogólnego poziomu funkcjonowania intelektualnego, oraz trudności w zachowaniu przystosowawczym występujące przed 18. rokiem życia" ${ }^{5}$. Zgodnie z klasyfikacją ICD-10 niepełnosprawność intelektualną w stopniu umiarkowanym (F71) orzeka się u dorosłych ludzi wyróżniających się ilorazem inteligencji IQ pomiędzy 39 a 45 (w skali Wechslera) ${ }^{6}$, przy spełnionym dodatkowym kryterium obniżenia poziomu funkcjonowania społecznego oraz kryterium ujawnienia się problemu $\mathrm{w}$ wieku rozwojowym. Istnieje wiele dostępnych rozbudowanych charakterystyk tych osób ${ }^{7}$, ale ich główne trudności, będące przejawem dysfunkcjonalności, można sprowadzić do takich obszarów, jak:

${ }^{3}$ Ibidem.

${ }^{4}$ J. Meder, Rehabilitacja, [w:] Psychiatria. Tom II. Podstawy psychiatrii, red. A. Bilikiewicz, J. Rybakowski, S. Pużyński, J. Wciórka, Wydawnictwo Medyczne Urban \& Partner, Wrocław 2002, s. 301-317.

5 The International Classification of Diseases - ICD, [online] http:/ / www.who.int/ classifications/icd/ [dostęp: 20.12.2016].

${ }^{6}$ Ibidem.

${ }^{7}$ K. Bobińska, T. Pietras, P. Gałecki, Niepetnosprawność intelektualna - etiopatogene$z a$, epidemiologia, diagnoza, terapia. Wydawnictwo Continuo, Wrocław 2012; R.J. Kijak, Niepetnosprawność intelektualna: Między diagnoza a działaniem, Centrum Rozwoju 
- spostrzeganie: sprawność spostrzegania obniżona, spostrzega cechy konkretne, nie odróżnia cech ważnych;

- uwaga: trudności z koncentracją uwagi dowolnej, przewaga uwagi mimowolnej;

- pamięć: ograniczony zakres pamięci, bardzo słabe tempo uczenia się;

- mowa: opóźniony rozwój mowy, proste zdania, wymowa wadliwa i niewyraźna, ograniczony słownik, brak pojęć abstrakcyjnych;

- myślenie: ograniczone rozumowanie przyczynowo-skutkowe, wolne tempo i sztywność, brak samodzielności i ograniczona samokontrola;

- emocje: duża wrażliwość emocjonalna, ograniczona kontrola emocjonalna, labilność i ambiwalencja emocjonalna;

- motoryka: dość dobra samoobsługa, ruchy mało precyzyjne, niezgrabne, wolne tempo czynności ruchowych;

- dojrzałość społeczna: można obserwować ograniczenia w przystosowaniu społecznym i samodzielności, a maksymalny poziom dojrzałości społecznej porównywany jest do weku normalnie rozwijającego się 10-latka;

- nauka: możliwa jest nauka w szkole podstawowej specjalnej, czasami w tzw. szkole życia, przyuczenie do prostych czynności zawodowych, aktywizacja w Warsztatach Terapii Zajęciowej;

- praca: osoba jest wyuczalna w prostych czynnościach zawodowych, pod nadzorem obsługuje proste maszyny i urządzenia, zakłady pracy chronionej ${ }^{8}$.

Jak widać, osoby z niepełnosprawnością intelektualną w stopniu umiarkowanym w każdej dziedzinie codziennego życia napotyka-

Zasobów Ludzkich, Warszawa 2013; R. Piotrowicz, E. Wapiennik, Charakterystyka osób z niepetnosprawnościa intelektualną, [w:] Pedagogika specjalna dla pracowników socjalnych, red. D.M. Piekut-Brodzka, J. Kuczyńska-Kwapisz, Wydawnictwo APS, Warszawa 2004.

$8 \dot{Z}$. Stelter, Charakterystyka niepetnosprawności intelektualnej. Zagadnienia szczegótowe, [w:] „Dobry Start” - szkolenia dla ustugodawców osób niepetnosprawnych, Poznań 2006, s. 91-94. 
ją poważne ograniczenia uzależniające je od pomocy innych, a wspomniana percepcja czasu wiąże się z praktycznie z każdym z wyróżnionych obszarów funkcjonowania społecznego. Ograniczona samodzielność i potrzeba wsparcia jest zarówno cechą charakterystyczną osób z niepełnosprawnością intelektualną, jak i różnicującą tę populację ze względu na zakres i stopień tego wsparcia: od incydentalnego, okresowego przez ograniczone i rozległe aż do wsparcia permanentnego, wszechobecnego we wszystkich czynnościach i obszarach życia ${ }^{9}$. Osoby z umiarkowaną niepełnosprawnością intelektualną wymagają pomocy ograniczonej, jednak już zakres tego ograniczenia pozostaje problematyczny, gdyż właśnie $\mathrm{w}$ tej subtelnie zaznaczonej sferze kryje się potencjał usamodzielniania vs. ryzyko nadopiekunczego blokowania potencjału rozwojowego tych osób10. Zdaniem S. Kowalika, najbardziej zasadniczym wyróżnikiem sytuacji osoby niepełnosprawnej - co odnosi się także do osób niepełnosprawnych intelektualnie - jest nieadekwatność wymagań społecznych względem możliwości ich spełniania. W ocenie Tadeusza Majewskiego i Cezarego Miżejewskiego osoby z niepełnosprawnością intelektualną w stopniu umiarkowanym można uznać za względnie samodzielne w wykonywaniu czynności samoobsługowych i radzeniu sobie z problemami pojawiającymi się w codziennych sytuacjach życiowych ${ }^{11}$, a ich potencjał - jak można wnioskować z badań Beaty Cytowskiej - umożliwia

9 R.J. Kijak, op. cit.

${ }^{10}$ B. Tylewska-Nowak, Wypetnianie zadań rozwojowych przez osoby doroste z umiarkowaną i znaczna niepetnosprawnościa intelektualna, [w:] Dorośli z niepetnosprawnościa intelektualna w labiryntach codzienności. Analiza badań - krytyka podejść - propozycje rozwiąań, red. B. Cytowska, Wydawnictwo Adama Marszałek, Toruń 2011; M. Kościelska, Przeżywanie własnej $i$ cudzej dorostości przez osoby z niepetnosprawnościa, [w:] Niepetnosprawność w zwierciadle dorosłości, red. R. Kijak, Oficyna Wydawnicza „Impuls", Kraków 2012.

11 T. Majewski, C. Miżejewski, Możliwości zawodowe różnych kategorii osób niepetnosprawnych, [w:] Gmina a niepetnosprawność. Podręcznik dla samorządów gminnych z zakresu aktywizacji zawodowej i rehabilitacji społecznej osób niepełnosprawnych, red. T. Majewski, C. Miżejewski, W. Sobczak, KIGR, Warszawa 2007, s. 72. 
również wykonywanie wielu prostych prac zawodowych ${ }^{12}$. Niestety, w Polsce niepełnosprawni ciągle jeszcze zbyt rzadko znajdują zatrudnienie. Wydaje się to symptomatyczne dla problemu pewnej przypadkowości w tak ważnym uwalnianiu tych osób od poczucia zależności ${ }^{13}$.

Podejmując się pracy z osobą z poważną niepełnosprawnością, należy pamiętać o kilku zmiennych, które będą tę pracę determinować. Po pierwsze mimo tego, że jest to osoba dorosła, nie można oczekiwać, że jej reakcje będą adekwatne do wieku biologicznego - osoby z niepełnosprawnością intelektualną w stopniu umiarkowanym mentalnie osiągają orientacyjnie poziom dziewięcioletniego dziecka, a więc musimy założyć, iż na tym poziomie należy sytuować zadania rozwojowe i edukacyjne. Po drugie należy pamiętać o godności i poczuciu podmiotowości podopiecznego oraz o ryzyku nadmiernej infantylizacji relacji $\mathrm{z}$ nim${ }^{14}$. Trzeba więc zwracać się do niego z należytym szacunkiem oraz poważaniem, wzmacniając podmiotowość i prawo dokonywania wyborów. Nawet przy poważnym ograniczeniu zdolności intelektualnych traktowanie osoby $\mathrm{z}$ niepełnosprawnością intelektualną jak partnera zależy od dwóch czynników: od nasyconej szacunkiem dla podmiotowości postawy opiekuna oraz od ukształtowania rzeczywistych kompetencji społecznych podopiecznego na miarę jego możliwości, w tym umiejętności mówienia we własnym imieniu (kompetencje self-adwokata $\left.{ }^{15}\right)$, umiejętności dokonywania wyborów i asertyw-

12 B. Cytowska, Realizacja programu „Wspomagane zatrudnienie osób z niepetnosprawnościa intelektualną - Trener", [w:] Pedagogika specjalna - koncepcje i rzeczywistość. Socjopedagogiczne aspekty rehabilitacji osób niepełnosprawnych. Tom III, red. T. Żółkowska, M. Wlazło, Uniwersytet Szczeciński, Szczecin 2008.

13 B. Tylewska-Nowak, op. cit.; M. Kościelska, op. cit.; R.J. Kijak, op. cit., s. 12.

14 E. Pisula, Dorostość osób z niepetnosprawnością intelektualna - szanse i zagrożenia, PSOUU, Zarząd Główny, Warszawa 2008; B. Tylewska-Nowak, op. cit.

15 D. Podgórska-Jachnik, D. Tłoczkowska, Ruch self-adwokatów jako rozwijanie kompetencji w zakresie rzecznictwa wtasnego osób z niepetnosprawnościa intelektualna, [w:] D. Podgórska-Jachnik, Problemy rzecznictwa i reprezentacji osób niepetnosprawnych, Wydawnictwo WSP, Łódź 2009. 
ności. Tę ostatnią sferę kompetencji podnosi explicite nowa podstawa programowa dla osób z niepełnosprawnością w stopniu umiarkowanym i znacznym ${ }^{16}$.

\section{Przygotowanie do realizacji "treningu czasu"}

Przystępując do pracy z osobami z niepełnosprawnością intelektualną, należy dokonać najpierw szczegółowej diagnozy ich ograniczeń i zachowanych zasobów oraz oceny sytuacji, w jakiej funkcjonują. Na początek opracowania strategii pracy z podopiecznym - warto określić jego mocne oraz słabe strony. W praktyce działań oligofrenopedagogów jedną z najbardziej użytecznych technik diagnostycznych okazała się Skala umiejętności społecznych Gunzburga PAC. Jako całość17 składa się ona z trzech inwentarzy o rosnącym stopniu trudności zadan - pozwala to określić aktualny poziom rozwoju wychowanka oraz poznać strefę najbliższego rozwoju, dzięki czemu można trafnie zaplanować oddziaływania wychowawcze. Ponadto można określić, jakich zadań podopieczny nie da rady obecnie, a których prawdopodobnie nigdy wykonać, ze względu na istniejące ograniczenia i deficyty. W planowaniu pracy należy pogodzić optymizm pedagogiczny z realizmem ${ }^{18}$ - obydwa wyznaczają sposób myślenia o celach rehabilitacji i osiągnięciach uzyskiwanych przez podopiecznego. Sprawności badane w Inwentarzu PAC dzieli się na cztery grupy: obsługiwanie siebie, komunikowanie się, uspołecznienie, zajęcia. W każdej z grup znajdują się

16 Zob. Rozporzadzenie Ministra Edukacji Narodowej z dnia 27 sierpnia 2012 r. w sprawie podstawy programowej wychowania przedszkolnego oraz ksztatcenia ogólnego w poszczególnych typach szkót (Dz. U. z 2012 r., poz. 977), Załącznik nr 3: Podstawa programowa kształcenia ogólnego dla uczniów z upośledzeniem umysłowym w stopniu umiarkowanym lub znacznym w szkołach podstawowych i gimnazjach.

17 PPAC, PAC-1 oraz PAC-2, [w:] T. Witkowski, Podręcznik do inwentarza PAC-1H.C. Gunzburga do oceny postępu w rozwoju społecznym osób z upośledzeniem umystowym, Katolicki Uniwersytet Lubelski, Lublin 1996.

18 Por. B. Tylewska-Nowak, op. cit. 
zadania o rosnącym stopniu trudności, adekwatne dla danej kategorii. Zaleca się, by badanie przeprowadzać co pół roku, dzięki czemu widać będzie w których obszarach funkcjonowania nastąpił progres, a w których regres ${ }^{19}$.

Badanie orientacji w czasie, któremu poświęcone jest niniejsze opracowanie, możemy badać na poziomie drugim i trzecim, a więc PAC-1 oraz PAC-2. Inwentarz PAC-1 H.C. Gunzburga do oceny postępu $w$ rozwoju społecznym osób $z$ upośledzeniem umysłowym zawiera $\mathrm{w}$ tej kategorii następujące zadania:

- poprawnie używa określeń: z rana, po południu,

- nazywa dni tygodnia i wszystkie dobrze rozumie,

- ujmuje różnice między: dzień - tydzień, minuta - godzina itp.,

- odróżnia kwadrans od godziny,

- podaje czas i kojarzy godziny na zegarze z różnymi czynnościami i zdarzeniami ${ }^{20}$.

Inwentarz PAC-2 przeznaczony jest do badania osób z niepełnosprawnością intelektualną $\mathrm{w}$ stopniu lekkim, zawiera więc zadania nieco trudniejsze, na wyższym poziomie, jednak w myśl metodyki Strefy Najbliższego Rozwoju także przy nieco głębszych stopniach niepełnosprawności intelektualnej należy traktować go jako obszar tzw. nurkowania, a więc poszukiwania potencjalnych zasobów podopiecznego. W obszarze tym znajdą się więc takie zadania, w których oczekujemy, że uczeń - chociaż trochę i chociaż z pomocą:

- rozumie przymiotniki: codzienny, krótki, punktualny, częsty, powtarzany,

- podaje czas, a godziny na zegarze kojarzy z różnymi czynnościami i zdarzeniami,

- rozumie różne odpowiedniki tego samego czasu, np. 9.15 kwadrans po dziewiątej,

- pisze pod dyktando czas zegarowy,

- rozumie odstępy czasowe, np. między godziną 3.30 a 4.30,

${ }^{19}$ http://www.poradnikautystyczny.pl/post/kwestionariusze/skala_umiejet nosci_spolecznych_gunzburga_pac [dostęp: 31.12.2016].

20 T. Witkowski, Podręcznik do inwentarza PAC-1H..., s. 7-8. 
- umie poprawnie określić czas $\mathrm{w}$ godzinę albo dwie po lub przed momentem, który mu się w danej chwili wskaże,

- umie posługiwać się linijką, taśmą do mierzenia itp. i rozumie pojęcia: „pół”, „ćwierć" 21.

Badanie przeprowadza się na podstawie obserwacji oraz wywiadu, a odpowiedzi zaznacza na przygotowanym diagramie. Dzięki analizie zebranych danych można opracować plan oddziaływań wychowawczych, a po czasie dokonać ich ewaluacj poprzez porównanie diagnozy wstępnej z wynikami uzyskanymi w kolejnym badaniu.

Użyteczna dla celów „treningu czasu" może być też diagnoza za pomocą Skali Przystosowania Społecznego N.C. Conkeya, J. Walsha w polskim łłumaczeniu i modyfikacji Władysławy Pileckiej i Danuty Wolskiej22. Kwestionariusz pozwala wykreślić profile takich umiejętności społecznych jak: komunikowanie się, samodzielność, samoobsługa. Posługiwanie się pojęciem czasu traktowane jest jako jedna ze zdolności społecznych, obok czytania, pisania i posługiwania się pieniędzmi. $W$ kwestionariuszu orientacja $\mathrm{w}$ czasie to jeden z czynników samodzielności, a ocenić ją można w oparciu o następujące wskaźniki obserwacyjne:

- regularnie używa zegarka na rękę lub zegarka ściennego do sprawdzania czasu czynności np. kiedy może zadzwonić przyjaciel;

- potrafi odczytać godzinę i minutę z zegara ściennego lub na rękę;

- wie, która jest godzina, korzystając z zegara ściennego;

- pokazuje swoim zachowaniem, że umie rozróżnić kilka wydarzeń dnia np. początek programu telewizyjnego ${ }^{23}$.

${ }^{21}$ T. Witkowski, Podręcznik do inwentarza PAC-2 H. C. Gunzburga do oceny postępu w rozwoju społecznym osób z upośledzeniem umysłowym, Katolicki Uniwersytet Lubelski, Lublin 1996, s. 7-9.

22 D. Wolska, Wptyw prawidłowego przystosowania społecznego na jakość życia osób dorostych z niepetnosprawnościa intelektualną, [w:] Dorośli z niepetnosprawnościa intelektualna w labiryntach codzienności. Analiza badań - krytyka podejść - propozycje rozwiąań, red. B. Cytowska, Wydawnictwo Adam Marszałek, Torun 2011, s. 63-69.

${ }^{23}$ Ibidem, s. 66. 
O braku orientacji świadczy, to że wydaje się, iż osoba nie zdaje sobie sprawy z upływu czasu.

Wskaźniki ujęte w Kwestionariuszu Conkeya i Walsha można także wykorzystać do projektowania ćwiczeń w ramach "treningu czasu”, choć stopień ich ogólności jest większy niż w przypadku diagnozy Inwentarzem Gunzburga.

\section{Doświadczenia własne $z$ „treningiem czasu” - założenia metodologiczne studium przypadku i diagnoza wstępna}

Dla zilustrowania doświadczeń własnych z treningiem pojęcia i zarządzania czasem wybrałam studium przypadku Krzysztofa24 młodego, dorosłego mężczyzny z niepełnosprawnością intelektualną w stopniu umiarkowanym, mieszkańca małej miejscowości, mieszkającego w domu rodzinnym wspólnie z rodzicami. Rodzice, silnie związani emocjonalnie z synem, zawsze szukali pomocy profesjonalistów, tak by możliwie w jak najlepszy sposób wykorzystać jego potencjał. Niestety: okres, w jakim urodziło się ich jedyne dziecko (prawie trzydzieści lat temu) oraz miejsce (małe miasteczko na prowincji) były czynnikami niesprzyjającymi ich oczekiwaniom. W konsekwencji nie byli oni nawet świadomi, co tak naprawdę stanowi istotę problemów rozwojowych ich syna, a wszelkie działania rehabilitacyjno-terapeutyczne podejmowali w sposób przypadkowy. Krzysztof karierę edukacyjną rozpoczął w ogólnodostępnej zerówce. Naukę kontynuował w ogólnodostępnej szkole podstawowej, jednak po ukończeniu trzeciej klasy został przeniesiony do szkoły specjalnej, gdzie dokończył naukę. Od 10 lat Krzysztof uczestnicy w zajęciach organizowanych przez Środowiskowy Dom Samopomocy (8 godzin dziennie we wszystkie dni robocze). Działania podejmowane z dorosłym już Krzysztofem miały więc charakter kompensacyjny, gdyż wiele z umiejętności mógłby opanować już wcześniej. Należy zaznaczyć, że zarówno matka, jak i ojciec byli

${ }^{24}$ Imię, jak i niektóre inne informacje o badanej osobie ułatwiające jej identyfikację zostały zmienione w celu ochrony jej dóbr osobistych. 
bardzo chętni do pracy - potrzebowali jedynie wskazówek i wsparcia oraz czasu i cierpliwości.

Ponieważ podjęty projekt realizowany i dopasowany był do indywidualnych potrzeb mężczyzny, w jego domu, poza placówką rehabilitacyjną (w tym czasie korzystał także z zajęć w Środowiskowym Domu Samopomocy), podjęte zadanie można było potraktować jak formę badań w działaniu. Badania w działaniu (ang. action research) - jako forma zaangażowanej i refleksyjnej działalności pedagogów - są w naukach społecznych uznanymi metodologicznie studiami nad sytuacją społeczną, w której znajduje się badacz, z zamiarem jej ulepszenia; ukierunkowanymi na poprawę jakości działania w jej obrębie 25 .

Podjęte przeze mnie badania można uznać za mikroprojekt, gdyż ich celem była nie tylko poprawa funkcjonowania Krzysztofa, ale także całej rodziny w codziennych sytuacjach życiowych, w których także $\mathrm{z}$ racji zaangażowania $\mathrm{w}$ projekt przez dłuższy okres czasu systematycznie uczestniczyłam. Zajęcia wpisywały się w tę codzienność, były jej częścią, miały dla mnie osobiste znaczenie - co $\mathrm{z}$ góry zdefiniowało również moja rolę $\mathrm{w}$ procesie badawczym. Zgodnie z podstawowymi założeniami metodologicznymi ${ }^{26}$ badania w działaniu bowiem:

- są prowadzone przez tę samą osobę, która działa i podejmuje decyzje, łącząc rolę badacza i praktyka oraz zawsze odnoszą się do zagadnień/pytań, które mają znaczenia dla badacza - te warunki określiłam już wyżej;

- mają zawsze swoje praktyczne konsekwencje - tu: realną poprawę funkcjonowania osoby i jej rodziny;

- z działań praktycznych pozwalają doprowadzić do uogólnień teoretycznych - tu: propozycję metodyczną "treningu czasu”;

- odbywają się przy większym lub mniejszym współudziale uczestników sytuacji, w której przebiega badanie - tu: przy

${ }^{25}$ Badania w działaniu: Pedagogika $i$ antropologia zaangażowane, red. H. Červinková, D. Gołębniak, Wydawnictwo Naukowe DSW, Wrocław 2010.

${ }^{26}$ www.metologia-badan.wyklady.org/wyklad/7_badania-w-dzialaniu-actionresearch-.html [dostęp: 14.08.2017]. 
podmiotowym udziale Krzysztofa i wzmacnianiu jego podmiotowości oraz przy aktywnym zaangażowaniu rodziców.

Celem podjętych przeze mnie działań było poznanie oraz podwyższenie poziomu funkcjonowania podopiecznego $\mathrm{z}$ niepełnosprawnością intelektualną $\mathrm{W}$ stopniu umiarkowanym $\mathrm{w}$ obrębie kategorii czasu: podnieść poziom rozumienia i orientacji $\mathrm{w}$ czasie oraz zarządzania nim. Efekty pracy miały pomóc mu w codziennym funkcjonowaniu, a tym samym w życiu całej rodziny, przy czym zakres oczekiwanych zmian - ze względu na umiarkowany stopień niepełnosprawności intelektualnej - miał się sprowadzać do małych, ale zauważalnych kroków rozwojowych. Głównym problemem badawczym towarzyszącym podjętym działaniom (a więc zgodnie z metodologia action research - wtórnym wobec nich, a nie problemem badawczym samym w sobie) było pytanie: $W$ jaki sposób możliwe jest wzbogacenie i poszerzenie umiejętności - kompetencji zarządzania czasem przez osoby z niepełnosprawnością intelektualną w stopniu umiarkowanym? Realizacji programu towarzyszyła stała obserwacja uczestnicząca oraz zobiektywizowana diagnoza z wykorzystaniem skali obserwacyjnej (Inwentarz H.C. Guznburga), umożliwiająca ocenę zachodzących zmian i ewaluację projektu.

Pracę z Krzysztofem rozpoczęłam w lipcu 2014 r., gdy miał 26 lat. Znałam go już wcześniej, ale by móc realnie ocenić jego możliwości oraz późniejsze efekty pracy przeprowadziłam diagnozę za pomocą Inwentarza PAC-1 H.C. Gunzburga do oceny postępu w rozwoju społecznym osób z upośledzeniem umysłowym. Badanie trwało ok. $30 \mathrm{mi}-$ nut - w udzielaniu odpowiedzi do Inwentarza pomocna była matka Krzysztofa. Z analizy uzyskanych informacji wynikało, że Krzysztof:

- radzi sobie z podstawowymi czynnościami samoobsługowymi, wymaga jednak wsparcia przy trudniejszych zadaniach;

- nie porusza się samodzielnie nawet po najbliższej okolicy zawsze przebywa w towarzystwie opiekuna;

- opanował zasady higieny, jednak niechętnie poddaje się codziennej toalecie;

- nie potrafi wiązać butów, wstążek, krawatów itp.,

- ma trudności z długotrwałym skupieniem uwagi, a w konsekwencji z zapamiętaniem i wykonaniem szeregu czynności; 
- nie potrafi posługiwać się zegarkiem oraz nie rozumie pojęć temporalnych;

- ma kłopoty w rozróżnianiu poszczególnych nominałów pieniędzy, rozumie jednak, że pieniądze są w życiu ważne i należy je szanowa;

- nie potrafi czytać (nawet globalnie);

- odmawia uczestnictwa w sportowych aktywnościach grupowych;

- wymaga przypomnienia, zachęty i wsparcia, by podjąć się jakichkolwiek zadań w gospodarstwie domowym;

- ma niewielkie trudności związane z motoryką dużą.

Zajęcia z Krzysztofem odbywały się raz w tygodniu przez 1-2 godziny zegarowe (w zależności od potrzeb i zainteresowania zajęciami) przez okres trzech miesięcy. Był to czas na pracę indywidualną, rozmowę z Krzysztofem o jego potrzebach, zmartwieniach oraz oczekiwaniach, a także konsultacje z rodzicami. Na bieżąco, w ramach aktualnych potrzeb, wprowadzaliśmy wspólnie zmiany do naszego "treningu”, np. zmienialiśmy „spis czynności do wykonania" na tablicy korkowej. W tym samym czasie Krzysztof codziennie trenował wspólnie z rodzicami. Zaangażowanie rodziców zostało uznane za podstawowy warunek realizacji programu. Po upływie trzech miesięcy spotykaliśmy się raz w miesiącu, by omówić postępy oraz strategię pracy. Trudno mówić o jej zakończeniu, gdyż ustalone sposoby działania stały się częścią rutynowego sposobu funkcjonowania rodziny, co zresztą wynika z przyjętej metodologii refleksyjnej praktyki badań w działaniu.

\section{"Treningu pojęcia i zarządzania czasem" - propozycje ćwiczeń}

Kierując się wskazaniami teorii, zaleceniami dydaktycznymi27 oraz własnym doświadczeniem z badań nad czasem wolnym osób

27 J. Lausch-Żuk, Pedagogika osób z umiarkowanym, znacznym i głębokim upośledzeniem umystowym, [w:] Pedagogik a specjalna: praca zbiorowa, red. W. Dykcik, Wydaw- 
z niepełnosprawnością intelektualną28, chciałam przedstawić własną, autorską propozycję metodyczną "treningu pojęcia i zarządzania czasem" dla tych osób, ukazaną przez pryzmat programu zrealizowanego z Krzysztofem. Poza założeniami dotyczącymi treningów z osobami z niepełnosprawnością intelektualną, poczynionymi na wstępie, chciałam dodać kilka informacji uzupełniających. Otóż:

- określenie „trening pojęcia i zarządzania czasem” - krócej "trening czasu" - traktuję jako pewien skrót myślowy, dotyczący z jednej strony kształtowania pojęcia czasu, z drugiej nabywania kompetencji $\mathrm{w}$ praktycznych aspektach rozumienia jego przepływu oraz zarządzania nim we własnym życiu osoby z niepełnosprawnością intelektualną;

- subiektywne poczucie czasu w dużym stopniu zależy od codziennych doświadczeń osoby, będzie więc pochodną jej osobistych doświadczeń; zatem „trening czasu” (pojęcia czasu) to także trening w zakresie kształtowania, gromadzenia i nadawania znaczeń doświadczeniom indywidualnym takich osób;

- z racji powyższego "trening pojęcia czasu” należy traktować jako jeden $z$ treningów umiejętności społecznych, podnoszących potencjał adaptacyjny osób z różnego rodzaju deficytami w tym zakresie (np. deficyt doświadczeń, wzorców, umiejętności, deficyt możliwości intelektualnych ograniczających rozumienie różnych regulatorów życia społecznego itd.).

Treningi społeczne, zwane też treningami umiejętności społecznych (ang. soft skills workshops) służą kształceniu tych konkretnych umiejętności życia codziennego i samoobsługi, których deficyty

nictwo Naukowe UAM, Poznań 2006, s. 149-165; Przewodnik dla nauczycieli uczniów upośledzonych umystowo w stopniu znacznym i umiarkowanym, red. M. Piszczek, CMPP-P, Warszawa 2001; J. Wyczesany, Pedagogika upośledzonych umysłowo. Wybrane zagadnienia, Oficyna Wydawnicza „Impuls”, Kraków 2002; Dydaktyka specjalna wybrane zagadnienia, red. J. Wyczesany, HARMONIA UNIVERSALIS, Gdańsk 2014.

28 Badania prowadzone w ramach studiów doktoranckich na UKW w Bydgoszczy pod kierunkiem dr hab. D. Podgórskiej-Jachnik, prof. UKW, wcześniej pod opieką dr. hab. Mariusza Cichosza, prof. UKW. 
wykazała diagnoza sytuacji danej osoby ${ }^{29}$. Wymienia są wśród nich np.: trening kulinarny, planowania budżetu domowego, wyglądu zewnętrznego i higieny osobistej, komunikacji i prowadzenia rozmowy, przygotowania do podjęcia pracy i trening pracy, rozwiązywania problemów w sytuacjach międzyludzkich. Lista ta jednak nie jest zamknięta ${ }^{30}$. Z punktu widzenia barier $\mathrm{w}$ rozumieniu i zarządzania czasem, trening pojęcia czasu wydał mi się bardzo ważny w przypadku niepełnosprawności intelektualnej.

Moja propozycja ma charakter teoretyczno-praktyczny: z jednej strony nawiązuje do teoretycznych rozważań o możliwości rewalidacji w oligofrenopedagogice, $\mathrm{z}$ drugiej pokazuje pewne możliwe praktyczne rozwiązania $\mathrm{w}$ tym zakresie. Ten drugi aspekt musi zawsze uwzględniać konkretne realia i indywidualne potrzeby danej osoby i jej otoczenia. Także podjęcie pracy z Krzysztofem poprzedziła rozmowa z rodzicami: omówienie dokumentacji (wyjaśnienia zebranych przez lata diagnoz i opinii), podejmowanych dotychczas działań, a następnie problemów, oczekiwań oraz możliwości. Diagnoza funkcjonalna w oparciu o Inwentarz PAC pozwoliła ustalić, co Krzysztof już potrafi oraz co jest jeszcze w stanie (najprawdopodobniej) osiągnąć. Następnie uzgodniliśmy, jakie działania są w stanie regularnie i konsekwentnie podejmować rodzice. Wynikało to z potrzeby wspólnego frontu oddziaływań oraz potrzeby naprawdę intensywnego wpływu na zachowanie Krzysztofa, ale i rehabilitacyjnego znaczenia funkcjonowania $\mathrm{w}$ rolach rodzinnych osób z niepełnosprawnością intelektualną ${ }^{31}$. Do tego konieczne było ustalenie zakresu odpowiedzialności tak terapeuty, jak i rodziców. Naszym wspólnym celem, wypracowanym w toku wstępnych ustaleń, była większa aktywizacja i usamodzielnienie Krzysztofa. Oprócz ogólnego pobudzenia aktywności, przyjęliśmy zatem na początku trzy główne zadania w tym zakresie: 1) podniesienie po-

${ }^{29}$ D. Podgórska-Jachnik, Praca socjalna z osobami bezdomnymi, Centrum Rozwoju Zasobów Ludzkich, Warszawa, 2014, s. 113-115.

30 Ibidem, s. 114.

${ }^{31}$ J. Wyczesany, Pedagogika upośledzonych..., s. 147, 156-157. 
ziomu higieny osobistej, 2) zachęcenie do regularnego przyjmowania leków oraz 3) nauka systematyczności przy wykonywaniu drobnych prac w gospodarstwie domowym. Zadania były określone konkretnie, realistycznie i stanowiły pewne punkty do osiągnięcia w wytyczonych kierunkach działania. Podkreślić należy ograniczenie liczby tak ustanowionych celów oraz konieczność wpisania podjętych działań w codzienną aktywność mężczyzny. Pojęcie czasu i zarządzanie nim pojawiały się jako pragmatyczny, instrumentalny składnik realizowanych zadań, jak wyniknęło z realizacji projektu - ich wspólny mianownik i cel sam w sobie. Tak doszło do wyodrębnienia tytułowego treningu pojęcia i zarządzania czasem, który można traktować w kategoriach ćwiczenia tej konkretnej umiejętności.

Pierwszym etapem pracy było wzbudzenie motywacji do działania. By zachęcić biernego początkowo Krzysztofa do jakiejkolwiek aktywności, zastosowano na wstępie technikę tzw. ekonomii żetonowej, zwanej też punktową ${ }^{32}$. Posłużyła do tego korkowa tablica, na której umieszczone zostały piktogramy z działaniami, których wypracowanie uznane zostało za priorytet:

- piktogram „wyjście do środowiska” - oznaczał wyjście na zajęcia do Środowiskowego Domu Samopomocy;

- piktogram "tabletki” - oznaczał systematyczne przyjmowane przepisanych przez lekarza leków;

- piktogram „odniesienie naczyń po obiedzie” - oznaczał czynność samoobsługową, uznaną $\mathrm{w}$ treningu za podstawową (z wielu możliwych została wybrana ta, która była wystarczająco prosta, powtarzalna kilka razy dziennie, łatwa do wyodrębnienia i oceny efektywności jej wykonania);

- "umycie zębów” - podstawowy i codzienny zabieg higieniczny, którego znaczenia uzasadniać nie trzeba, a który nie stanowił dotąd nawyku Krzysztofa.

32 A. Kołakowski, A. Pisula, Sposób na trudne dziecko. Przyjazna terapia behawioralna, GWP, Gdańsk 2016; T. Ayllon, Jak stosować gospodarkę żetonowa i system punktowy, SPOA, Gdańsk 2000. 
$\mathrm{W}$ treningach prowadzonych $\mathrm{z}$ osobami z niepełnosprawnością intelektualną bardzo ważny jest - szczególnie na początku - prosty charakter podstawowych, najważniejszych zadań oraz ich powtarzalność i weryfikowalność.

Na tablicy oprócz piktogramów umieszczone były też nazwy dni tygodnia - całość miała formę przestrzennej matrycy, krzyżującej dni tygodnia i zaplanowanych zadań. Zadaniem Krzysztofa było codzienne wykonywanie wymienionych czynności bez marudzenia - jako wzmocnienie do tablicy przypinany był guziczek (guziczki były w różnych kolorach i kształtach, by trenować również kolejne sprawności - rozróżnianie barw oraz figur geometrycznych). Za negatywne zachowania (niewykonanie zadania) guziczki z tablicy były także odpinane. Przy pomocy tablicy rozwijaliśmy z Krzysztofem znajomość nazw dni tygodnia, systematyczność, pokazywaliśmy zależność działanie - skutek, a przy okazji uczyliśmy go także liczyć, co zostanie opisane w dalszej części tekstu. Zastosowana metoda łączyła zalecenia dydaktyczne metody ośrodków pracy (pomysł inspirowany był wykorzystaniem arkuszu obecności i kalendarza ściennego do kształtowania pojęcia czasu w czasie zajęć wstępnych) ${ }^{33}$ oraz efekt wzmocnień behawioralnych ${ }^{34}$ i behawioralnego podejścia do zarządzania kompetencjami ${ }^{35}$.

Drugim istotnym elementem było spisanie kontraktu z Krzysztofem. Zgoda i świadome zaangażowanie podopiecznego to istotny element całej strategii jego upodmiotowienia w toku realizacji programu. Wspólnie z Krzysztofem i jego rodzicami ustaliliśmy, że pozytywne zachowania będą gratyfikowane, zaś negatywne karane (odbieranie żetonów). „Walutą” miały być opisane wyżej kolorowe guziczki. Zastosowaliśmy następujące przeliczniki:

${ }^{33}$ K. Sadowska, Podstawowe założenia $i$ wartości metody ośrodków pracy w szkolnictwie specjalnym, „Nauczyciel i Szkoła” 2003, 1-2(18-19), s. 180-196.

${ }^{34}$ A. Zawiślak, Problemy autonomii osób dorostych z niepetnosprawnościa intelektualną: Nauki o edukacji, „Rocznik Naukowy Kujawsko-Pomorskiej Szkoły Wyższej w Bydgoszczy" 2008, Nr 3/, s. 41-59.

35 P. Jurek, P. Pawlicka, Kwestionariusz Diagnozy Funkcjonalnej: Podręcznik, Wydawnictwo Harmonia Universalis, Gdańsk 2015, s. 32. 
- 10 kolorowych guziczków był wart arkusz naklejek (Krzysztof z wielką pasją oddaje się wyklejaniu),

- 15 guzików - można wymienić na zeszyt do naklejek,

- 20 guzików - to wyjście Krzysztofa na lody z tatą,

- 30 guzików - to rodzinny wyjazd na pizzę,

Łatwo zauważyć, że mimo konkretnego charakteru wzmocnień (naklejki, lody, pizza), miały one także społeczny charakter ${ }^{36}$, podtrzymujący relacje wewnątrzrodzinne ${ }^{37}$.

Zbieranie guzików uczy nie tylko kolorów i kształtów, ale zmusza do liczenia - w naszym przypadku w zakresie trzydziestu, jednak jest to kwestia umowna, uzależniona od aktualnych możliwości podopiecznego. Ponadto zbieranie guzików pomaga w treningu cierpliwości, nagroda jest bowiem mniej lub bardziej odsunięta w czasie. Dodatkowo uczy sztuki wyboru: czy warto zbierać większą pulę domowej waluty na większą atrakcję, czy może jednak lepiej odebrać mniejszą nagrodę natychmiast? Zastosowanie guzików pozwoliło wprowadzić bardziej złożony system motywacji oparty na wspomnianej już gospodarce żetonowej38.

Skoro naszym głównym celem była nauka systematyczności i poczucia czasu, niezbędnym elementem okazał się zegarek ${ }^{39}$. Krzysztof rozróżniał cyfry i potrafił liczyć, niestety nie potrafił ich nazwać i powiązać z symbolicznym zapisem. Konieczny okazał się zegarek elektroniczny. Do ćwiczeń wykorzystano czasomierz z sygnalizatorem dźwiękowym, dzięki czemu co kwadrans można było usłyszeć krótki sygnał dźwiękowy. Dla Krzysztofa samo posiadanie

${ }^{36}$ M. Zielińska, A, Bagińska, Interwencja behawioralna w przypadku wystąienia skrajnej selekcji jedzenia, „Psychologia Rozwojowa”, tom 16, nr 3/2011, s. 73.

37 A. Kołakowski, A. Pisula, op. cit.

38 T. Ayllon, Jak stosować gospodarkę żetonowa i system punktowy, SPOA, Gdańsk 2000.

39 Pomysły wykorzystania zegarka miały charakter autorski, ale obecnie warto zainspirować się materiałami dydaktycznymi w belgijskiej broszurze: Praktijk in beeld. Tijd en planning. Hoe kan ik je tonen wat straks komt? (tłum. Praktyka w obrazie. Czas i planowanie. Jak mogę pokazać, co będzie później?), Sclera vzw \& Iris Visualisaties [b.r.], http://sclera.be/resources/pib/tijd/ [dostęp: 02.06.2017]. 
zegarka było nobilitacją - zegarek był synonimem dorosłości i samodzielności. Zajęcia objęły naukę rozróżniania godzin (tzn. rozpoznawania całości wizualnych wybranych zapisów godzin w formie elektronicznej, nie ich odczytywania), co zważywszy na nieznajomość cyfr, było i tak dużym wyzwaniem.

W konsekwencji powstał swoisty przestrzenny „zegar ścienny”. $\mathrm{Na}$ futrynie drzwi zostały zawieszone przez Krzysztofa kartki z kolorowymi obrazkami, ilustrującymi wybrane zdarzenia, sytuacje czynności ${ }^{40}$. Kartki malowane były wspólnie nie tylko za pomocą pędzli, ale też własnych rąk, waty, gazet itp. Chodziło o utrwalenie obrazów, z nadaniem im emocjonalnych znaczeń, a przy okazji Krzysztof uczył się mieszania kolorów oraz doświadczał stymulacji polisensorycznej ${ }^{41}$. Do kartek przyklejone zostały karteczki z zapisem godzinowym od 6.00 do 22.00, z wydrukowanymi godzinami co kwadrans $(6.00,6.15,6.30 \ldots$ itd.). Futryna bliżej łóżka zawierała godziny przedpołudniowe: od rana do 11.45, a po drugiej stronie znajdowały się godziny popołudniowe. Dzięki temu doszło do rozróżnienia pojęć „przed południem”/ „po południu”. Tak powstał szkielet naszego planu dnia. Za pomocą gotowych piktogramów oraz obrazków stworzonych przez Krzysztofa zaczęliśmy wypełniać plan dnia czynnościami wykonywanymi o konkretnych godzinach - od pobudki przez codzienne obowiązki po wieczorną toaletę.

Zadaniem rodziców było wspólne z Krzysztofem wieczorne przygotowanie odpowiedniego planu na następny dzień. Dzięki temu, że zegarek sygnalizował co kwadrans zmianę godziny, Krzysztof mógł skonfrontować liczby z cyferblatu z planem dnia. W konsekwencji wiedział, że nadchodzi pora konkretnej czynności. Uczyło to systematyczności, punktualności, porządkowało plan

40 Ze względu na brak niektórych piktogramów część obrazków musieliśmy przygotować samodzielnie. Można jednak skorzystać z gotowych piktogramów sugeruję np. rozbudowany belgijski system Sclera Symbols, który do użytku własnego można bezpłatnie pobrać ze strony: www.sclera.be. System zawiera również symbole opisane w języku polskim.

${ }^{41}$ M. Charbicka, Integracja sensoryczna przez caty rok. Wydawnictwo Difin, Warszawa 2017. 
dnia, ułatwiało planowanie i zapanowanie nad grafikiem rodzinnym, a także podnosiło poczucie własnej wartości Krzysztofa, ponieważ doświadczał on $\mathrm{w}$ ten sposób samodzielności. W konsekwencji przyniosło to również większe poczucie niezależności wszystkich trzem stronom: Krzysztofowi, jego rodzicom oraz mnie jako terapeutce.

Kolejnym elementem treningu było uświadomienie Krzysztofowi znaczenia i zastosowania pojęć temporalnych. W czasie rozpoczęcia treningów dla Krzysztofa wszystko co było - wydarzało się „wczoraj”, a wszystko co będzie - miało wydarzać się „jutro”, nawet jeśli zaplanowane było np. w następnym miesiącu. Mężczyzna odróżniał więc zdarzenia, a tym samym czas przeszły od przyszłego, jednak bez zrozumienia skali tej przeszłości i przyszłości. W związku z tym, że Krzysztof potrafił względnie dobrze liczyć (odliczać), problemem było uświadomienie, za ile dni odbędzie się konkretne wydarzenie. Posłużył do tego kalendarz z okienkiem. Najpierw przy pomocy rodziców ustaliliśmy, kiedy odbywają się ważne dla rodziny wydarzenia: urodziny, imieniny, rocznice, święta czy wakacje. Wtedy Krzysztof przy konkretnych datach rysował obrazek, który umownie informował o danym wydarzeniu. $\mathrm{Na}$ przykład torcik i uśmiechnięta twarz kobiety z kręconymi włosami symbolizowały urodziny mamy, a kwiatki i twarz mężczyzny w okularach narysowane były w dniu imienin taty. Codziennie rano, po przebudzeniu Krzysztof przesuwał okienko kalendarza o jedno pole, a ramka wskazywała, jaka konkretnie data jest dzisiaj. Ponadto, dzięki symbolom przy ważnych wydarzeniach można było odliczać dni do święta, przy okazji trenując liczenie (dni). Poza tym podczas wspólnych spotkań wracaliśmy do wydarzeń z przeszłości: pozwalały na to pytania, np. o to, co wydarzyło się trzy dni temu lub jakie święto było w poniedziałek. Wymuszało to nie tylko aktywną pracę $\mathrm{z}$ kalendarzem, ale też odszukanie $\mathrm{w}$ pamięci sytuacji z przeszłości.

$\mathrm{Na}$ bardziej zaawansowanym etapie można by było wprowadzić pomoc w postaci linii czasu (ang. timeline), graficznej reprezentacji chronologicznej sekwencji zdarzeń - przeszłych lub przy- 
szłych, zalecanej jako jedna z aktywnych metod nauczania poprzez porządkowanie informacji w czasie ${ }^{42}$ (np. faktów historycznych, choć nie tylko), a więc jednoczesnego zdobywania wiedzy z pewnego obszaru, jak i pogłębiania rozumienia zjawiska czasu. Harmonogram osobisty może być także pewną formą linii czasu, przy czym w języku angielskim odróżnia się te dwa rodzaje uporządkowań, jako timeline i timetable ${ }^{43}$. Oba mogą być pomocne $\mathrm{w}$ „treningu czasu". Kalendarz z okienkiem (okienkami) - jak w przypadku Krzysztofa - może być wstępem do pracy z harmonogramem (timetable) i linią czasu (timeline).

By utrwalić wytrenowane możliwości warto skorzystać z gotowych narzędzi, w opisywanym przypadku z systemu pomocy edukacyjnych PUS (Pomyśl - Ułóż - Sprawdź). Przy pomocy zestawu klocków oraz książeczki Matematyka konkretna, Część 2. Zegar i kalendarz ${ }^{44}$, Krzysztof mógł w formie zabawy sprawdzić samodzielnie własną skuteczność w działaniu. Dodatkową zaletą była zachęta do korzystania z książek oraz uświadomienie, że nauka nie musi być obciążeniem. Plusem serii PUS jest duża ilość gotowych materiałów z różnych tematów, które można zastosować przy rozwijaniu kolejnych umiejętności, po zaznajomieniu podopiecznego z zasadą korzystania z tej pomocy oraz możliwości samokontroli poprawności wykonania zadania.

\section{Efekty "treningu czasu” w analizowanym studium przypadku}

Pierwsze zmiany w aktywności Krzysztofa zostały zauważone po ok. trzech tygodniach: bez upominania zaczął wykonywać drob-

42 E. Brudnik, A. Moszyńska, B. Owczarska, „Ja i mój uczeń pracujemy aktywnie” przewodnik po metodach aktywizujacych, Zakład Wydawniczy SFS, Kielce 2000.

43 Por. https://en.wiktionary.org/wiki/timeline [dostęp: 14.08.2017].

${ }^{44}$ D. Pyrgies, Matematyka konkretna, Część 2. Zegar i kalendarz, Seria PUS, Wydawnictwo Epideixis, Lublin 2012. 
ne pracy domowe oraz przyjmować leki, ponadto zaczął posługiwać się kalendarzem z okienkiem oraz planem dnia, co pomogło mu się wyciszyć i uspokoić (zadania te wprowadziły przewidywalność i rutynę do jego życia). Można uznać, że główne cele „treningu czasu" zostały osiągnięte już po ok. pięciu tygodniach: Krzysztof wyrobił nawyk samodzielnego przyjmowania leków oraz mycia zębów, a także dobrowolnie i chętnie zaczął uczestniczyć w drobnych pracach domowych. Było to dla rodziców impulsem do samodzielnej modyfikacji tablicy oraz kontraktu - dołożenia nowych zadań oraz nagród. Dzięki temu trening (z modyfikacjami) trwa nieprzerwanie od trzech lat, a decyzja o jego kontynuacji należy do Krzysztofa i jego rodziców. Właściwie przestało to już być treningiem, ale formą planowania i zarządzania codziennym czasem w tej rodzinie. Praca z systemem PUS zachęciła Krzysztofa do sięgania po inne książki z łamigłówkami i rozwiązywania zadań postawionych przez rodziców. Dzięki stosowania kalendarza z okienkiem udało się wprowadzić do zasobu słów Krzysztofa pojęcie "później” (zamiast ,jutro") oraz „kiedyś” zamiast „wczoraj” - niestety konkretna orientacja $\mathrm{w}$ czasie (np.: w miniony poniedziałek/za cztery dni/w lipcu) ze względu na brak umiejętności abstrakcyjnego myślenia jest $\mathrm{w}$ tym momencie niemożliwa. Prawdopodobnie nieosiągalna jest także w przyszłości, choć formy te stosowane są w komunikacji z Krzysztofem i w miarę możliwości wizualizowane.

Krzysztof zaczął stosować w wypowiedziach o rzeczach dla niego ważnych opisy sytuacji zawierające wskazówki temporalne, np.: W wakacje, jak było ciepło, byłem ze "środowiskiem" w górach co znacznie ułatwia odbiorcy komunikatu orientację czasową. Oznacza również pojawiającą się u Krzysztofa potrzebę osadzania (porządkowania) wydarzeń w czasie. Kalendarz dnia pozwolił na usystematyzowanie niektórych czynności i pomógł zrozumieć, że pewne zjawiska są nieuniknione - napływają w strumieniu czasu. Piktogramy z podpisami dały zaskakujący i nieprzewidywany pierwotnie efekt: Krzysztof zaczął czytać całościowo. Rodzice przyjmują nowe osiągnięcia syna $\mathrm{z}$ radością, a nawet wzruszeniem, co dostarcza mu dodatkowych wzmocnień. Wszystko to świadczy o wartości 
i znaczeniu podjętego długoterminowego wysiłku w pracy z osobą $\mathrm{z}$ niepełnosprawnością intelektualną w stopniu umiarkowanym.

W celu zobiektywizowania wyników badań po pół roku od rozpoczęcia projektu, czyli w styczniu 2015 r. dokonałam ponownej diagnozy Krzysztofa za pomocą tego samego Inwentarza PAC-1, który posłużył diagnozie wstępnej. Porównanie wyników upoważnia do wniosku, że dzięki systematycznej oraz konsekwentnej pracy udało się wypracować progres w rozwoju społecznym mężczyzny utrzymane zostały nie tylko dotychczas wypracowane kompetencje, ale poszerzony został zakres jego samodzielności (w niektórych obszarach, oczywiście nie wszystkich, z pewnością związane to było z przeprowadzonym "treningiem czasu”). W innych sferach zaszły zmiany wynikające także $\mathrm{z}$ lepszego wglądu w potrzeby i możliwości Krzysztofa, co było efektem uwrażliwienia wychowawczego jego rodziców. W szczególności warto powiedzieć, że:

- Krzysztof zaczął sam podejmować inicjatywę podczas czynności samoobsługowych oraz prac w gospodarstwie domowym;

- Krzysztof zaczął sam poruszać się po terenie swojej rodzinnej miejscowości (wymaga wsparcia przy przechodzeniu przez jezdnię, w najbliższej okolicy brak jest przejścia z sygnalizatorem, ruch w okolicy jest wzmożony, więc ze względu na bezpieczeństwo mężczyzny zrezygnowaliśmy z treningu tej umiejętności);

- by nie stresować Krzysztofa i nie upokarzać go, zastąpiono buty sznurowane butami na rzep, dzięki czemu mężczyzna w pełni samodzielnie potrafi ubrać wszystkie części garderoby;

- dzięki piktogramom z podpisami na planie dnia Krzysztof zaczął czytać globalnie;

- Krzysztof coraz sprawniej posługuje się zegarkiem elektronicznym, a w wypowiedziach poprawnie używa pojęć temporalnych;

- dzięki zwiększonej samodzielności wzrosło poczucie własnej wartości Krzysztofa, co z kolei zaowocowało zwiększoną chęcią uczestnictwa w aktywnościach grupowych.

Przez sześć miesięcy regularnej pracy i przemyślanego „treningu czasu” udało się wyeliminować trudności, z którymi najbliżsi 
Krzysztofa nie potrafili sobie wcześniej poradzić. Efektem wspólnych działań było nie tylko uspołecznienie Krzysztofa, ale także podwyższenie komfortu funkcjonowania całej rodziny. Realizacja projektu dowiodła także, że można i warto podejmować działania kompensujące braki w umiejętnościach społecznych osób z niepełnosprawnością intelektualną nawet po osiągnięciu przez nich wieku wskazującego na dorosłość. Dotyczy to także umiejętności zarządzana czasem.

\section{Zakończenie}

Jak widać na podstawie opisanego wyżej przykładu, rozumienie pojęcia czasu oraz zarządzanie nim nie jest czymś nieosiągalnym w przypadku osób z niepełnosprawnością intelektualną w stopniu umiarkowanym. Przy pomocy niewielkiego nakładu finansowego oraz pomysłów wpisanych w rutynową aktywność, można zapewnić nie tylko płaszczyznę wspólnych działań dla całej rodziny, ale przede wszystkim wytrenować dobre nawyki, nauczyć systematyczności oraz zorganizować w aspekcie temporalnym życie codzienne takiej osoby. Najważniejsza w tym wszystkim jest jednak trafna wstępna diagnoza potrzeb, ocena sytuacji i posiadanych zasobów, systematyczność i zaangażowanie całej rodziny do wspólnej pracy. Przygotowywanie piktogramów i omawianie planu dnia zacieśnia nie tylko relacje pomiędzy poszczególnymi członkami, ale uczy też poszanowania przestrzeni i czasu drugiego człowieka. W przypadku pracy z Krzysztofem zaangażowanie rodziców zbliżyło ich do syna i pomogło zrozumieć jego trudności w orientacji w otoczeniu, dzięki czemu łatwiej im teraz szukać kolejnych rozwiązań uczących samodzielności, wychodzących poza wstępne ustalone cele "treningu czasu”. Sam Krzysztof zaczął pojmować zalety planowania i punktualności, a także systematyczności. Dało mu to poczucie samodzielności i niezależności, dzięki czemu jego poczucie własnej wartości znacznie wzrosło. W efekcie chętniej pracuje i podejmuje kolejne wyzwania. 


\section{Bibliografia}

Ayllon T., Jak stosować gospodarkę żetonowa i system punktowy, SPOA, Gdańsk 2000.

Bobińska K., Pietras T., Gałecki P., Niepetnosprawność intelektualna - etiopatogeneza, epidemiologia, diagnoza, terapia. Wyd. Continuo, Wrocław 2012.

Badania w działaniu: Pedagogika i antropologia zaangażowane, red. H. Červinková, D. Gołębniak, Wydawnictwo Naukowe DSW, Wrocław 2010.

Brudnik E., Moszyńska A., Owczarska B., "Ja i mój uczeń pracujemy aktywnie" - przewodnik po metodach aktywizujacych, Zakład Wydawniczy SFS, Kielce 2000.

Charbicka M., Integracja sensoryczna przez caty rok, Wydawnictwo Difin, Warszawa 2017.

Cytowska B., Realizacja programu „Wspomagane zatrudnienie osób z niepetnosprawnościa intelektualna - Trener" [w:] Pedagogika specjalna - koncepcje i rzeczywistość. Socjopedagogiczne aspekty rehabilitacji osób niepetnosprawnych. Tom III, red. T. Żółkowska, M. Wlazło, Uniwersytet Szczeciński, Szczecin 2008.

Dydaktyka specjalna wybrane zagadnienia, red. J. Wyczesany, HARMONIA UNIVERSALIS, Gdańsk 2014.

http://www.poradnikautystyczny.pl/post/kwestionariusze/skala_umiejetnosci_ spolecznych_gunzburga_pac [dostęp: 31.12.2016].

https://en.wiktionary.org/wiki/timeline [dostęp: 14.08.2017].

Jurek P., Pawlicka P., Kwestionariusz Diagnozy Funkcjonalnej: Podręcznik, Wydawnictwo Harmonia Universalis, Gdańsk 2015.

Kijak R.J., Niepetnosprawność intelektualną: Między diagnoza a działaniem, Centrum Rozwoju Zasobów Ludzkich, Warszawa 2013.

Kołakowski A., Pisula A., Sposób na trudne dziecko. Przyjazna terapia behawioralna, GWP, Gdańsk 2016.

Kościelska M., Przeżywanie własnej i cudzej dorosłości przez osoby z niepetnosprawnościa, [w:] Niepetnosprawność w zwierciadle dorosłości, red. R. Kijak, Oficyna Wydawnicza „Impuls”, Kraków 2012.

Lausch-Żuk J., Pedagogika osób z umiarkowanym, znacznym i głębokim upośledzeniem umystowym [w:] Pedagogik a specjalna: praca zbiorowa, red. W. Dykcik, Wydawnictwo Naukowe UAM, Poznań 2006.

Majewski T., Miżejewski C., Możliwości zawodowe różnych kategorii osób niepetnosprawnych, [w:] Gmina a niepetnosprawność. Podręcznik dla samorządów gminnych z zakresu aktywizacji zawodowej i rehabilitacji społecznej osób niepetnosprawnych, red. T. Majewski, C. Miżejewski, W. Sobczak, KIGR, Warszawa 2007.

Meder J., Rehabilitacja, [w:] Psychiatria. Tom II. Podstawy psychiatrii, red. A, Bilikiewicz, J. Rybakowski, S. Pużyński, J. Wciórka, Wydawnictwo Medyczne Urban \& Partner, Wrocław 2002. 
Piotrowicz R., Wapiennik E., Charakterystyka osób z niepetnosprawnościa intelektualna, [w:] Pedagogika specjalna dla pracowników socjalnych, red. D.M. Piekut-Brodzka, Kuczyńska- J. Kwapisz, Wydawnictwo APS, Warszawa 2004.

Pisula E., Dorosłość osób z niepetnosprawnościa intelektualna - szanse i zagrożenia, PSOUU, Zarząd Główny, Warszawa 2008.

Podgórska-Jachnik D., Praca socjalna z osobami bezdomnymi, Centrum Rozwoju Zasobów Ludzkich, Warszawa 2014.

Podgórska-Jachnik D., Tłoczkowska D., Ruch self-adwokatów jako rozwijanie kompetencji w zakresie rzecznictwa wtasnego osób z niepetnosprawnościa intelektualna, [w:] Podgórska-Jachnik D., Problemy rzecznictwa i reprezentacji osób niepetnosprawnych, Wydawnictwo WSP, Łódź 2009.

Przewodnik dla nauczycieli uczniów upośledzonych umysłowo w stopniu znacznym i umiarkowanym, red. M. Piszczek,, CMPP-P, Warszawa 2001.

Pyrgies D., Matematyka konkretna, Część 2. Zegar i kalendarz, Seria PUS, Wydawnictwo Epideixis, Lublin 2012.

Sadowska K., Podstawowe założenia $i$ wartości metody ośrodków pracy w szkolnictwie specjalnym, „Nauczyciel i Szkoła” 2003, 1-2(18-19).

Stelter Ż., Charakterystyka niepetnosprawności intelektualnej. Zagadnienia szczegótowe, [w:] „Dobry Start" - szkolenia dla ustugodawców osób niepetnosprawnych, Poznań 2006.

The International Classification of Diseases - ICD, [online] http://www.who.int/clas sifications/icd/ [dostęp: 20.12.2016].

Tylewska-Nowak B., Wypetnianie zadań rozwojowych przez osoby doroste z umiarkowana i znaczna niepetnosprawnością intelektualna [w:] Dorośli z niepetnosprawnością intelektualna w labiryntach codzienności. Analiza badań - krytyka podejść - propozycje rozwiazań, red. B. Cytowska, Wydawnictwo Adam Marszałek, Torun 2011.

Witkowski T., Podręcznik do inwentarza PAC-1H.C. Gunzburga do oceny postępu w rozwoju społecznym osób z upośledzeniem umysłowym, Katolicki Uniwersytet Lubelski, Lublin 1996.

Witkowski T., Podręcznik do inwentarza PAC-2 H. C. Gunzburga do oceny postęu w rozwoju społecznym osób z upośledzeniem umysłowym, Katolicki Uniwersytet Lubelski, Lublin 1996.

Wolska D., Wpływ prawidłowego przystosowania społecznego na jakość życia osób dorostych z niepetnosprawnościa intelektualna [w:] Dorośli z niepetnosprawnościa intelektualna w labiryntach codzienności. Analiza badań - krytyka podejść - propozycje rozwiązań, red. B. Cytowska, Wydawnictwo Adam Marszałek, Torun 2011.

www.metologia-badan.wyklady.org/wyklad/7_badania-w-dzialaniu-actionresearch-.html [dostęp: 14.08.2017].

Wyczesany J., Pedagogika upośledzonych umystowo. Wybrane zagadnienia, Oficyna Wydawnicza „Impuls”, Kraków 2002. 
Zawiślak A., Problemy autonomii osób dorostych z niepetnosprawnościa intelektualną: Nauki o edukacji, „Rocznik Naukowy Kujawsko-Pomorskiej Szkoły Wyższej w Bydgoszczy" 2008, nr 3.

Zielińska M., Bagińska A., Interwencja behawioralna w przypadku wystapienia skrajnej selekcji jedzenia, Psychologia Rozwojowa, tom 16, nr 3/2011. 